\title{
Protected Fresh Grapefruit Cultivation Systems: Antipsyllid Screen Effects on Environmental Variables inside Enclosures
}

\author{
Rhuanito S. Ferrarezi ${ }^{1,3}$, Alan L. Wright ${ }^{1}$, Brian J. Boman ${ }^{1}$, \\ Arnold W. Schumann ${ }^{2}$, Fred G. Gmitter ${ }^{2}$, and Jude W. Grosser ${ }^{2}$
}

ADDITIONAL INDEX WORDs. integrated production systems, protected agriculture, citrus under protective screen, agrometeorology, host-vector interactions

Summary. Huanglongbing (HLB) disease is a threat to most citrus (Citrus sp.) producing areas and is associated with the bacterium Candidatus Liberibacter asiaticus. The disease is transmitted by the vector asian citrus psyllid [ACP (Diaphoria citri)]. Antipsyllid screen houses can potentially reduce and eliminate HLB development in young citrus plantings by excluding the insect vector. These structures are also anticipated to represent a new environmental platform to cultivate high-valued fresh citrus. The purpose of this investigation was to evaluate the effect of screen houses on excluding infective ACP from inoculating grapefruit (Citrus $\times$ paradisi) trees and determine changes on environmental conditions caused by the screen cloth. We tested two coverings [enclosed screen house and open-air (control)] and two planting systems (in-ground and container-grown), with four replications arranged in a split-plot experimental design. Psyllid counting and HLB diagnosis were performed monthly, and the antipsyllid screen excluded the HLB vector from the houses. ACP and HLB-positive trees were found only at the openair plots. Weather monitoring was performed every 30 minutes from $22 \mathrm{Feb}$. to 31 July 2014. Solar radiation accumulation averaged $6.7 \mathrm{~W} \cdot \mathrm{m}^{-2} \cdot \mathrm{minute}^{-1}$ inside the screen houses and $8.6 \mathrm{~W} \cdot \mathrm{m}^{-2} \cdot$ minute $^{-1}$ in the open-air. Air temperature was greater inside the screen houses whereas wind gusts were higher in the open-air. Reference evapotranspiration accumulation averaged $3.2 \mathrm{~mm} \cdot \mathrm{day}^{-1}$ inside the screen houses and $4.2 \mathrm{~mm} \cdot \mathrm{day}^{-1}$ in the open-air. There was no difference in cumulative rainfall between screen houses and open-air. The antipsyllid screen houses reduced solar radiation, maximum wind gust, and reference evapotranspiration $\left(\mathrm{ET}_{\mathrm{o}}\right)$. The environmental conditions inside the protective screen houses are suitable for grapefruit production.

$\mathrm{C}$ itrus HLB disease is associated with the bacterium Candidatus Liberibacter asiaticus (CLas) in the United States and is vectored by the ACP. HLB was confirmed in São Paulo, Brazil, in 2004 and in

This work was funded by the University of Florida's Institute of Food and Agricultural Sciences (UF/IFAS) and by the United States Department of AgricultureFlorida Department of Agriculture and Consumer Services Specialty Crop Block Grant (project \#00092195). It is absolutely necessary to recognize Barrett R. Gruber and his profound contribution to this work. Gruber obtained the funding, designed the study, installed the infrastructure, collected data, and prepared an early draft of the manuscript before leaving the project in 2015

We thank J. Gersony, G. Britt, R. Burton, C. King, S. Finkley-Hines, D. Cole, C. Kirkland, and D. Ramirez for their technical assistance. We are grateful to $\mathrm{P}$. Stoffella and K. Folta for reviewing an early draft of this manuscript and providing critical suggestions.

${ }^{1}$ Institute of Food and Agricultural Sciences, Indian River Research and Education Center, University of Florida, Fort Pierce, FL 34945

${ }^{2}$ Institute of Food and Agricultural Sciences, Citrus Research and Education Center, University of Florida, Lake Alfred, FL 33850

${ }^{3}$ Corresponding author. E-mail: rferrarezi@ufl.edu.

doi: 10.21273/HORTTECH03790-17
Florida in 2005. Citrus trees affected by HLB show asymmetric, chlorotic, blotched, or mottled leaves; sparse growth; twig dieback; and malformed, off-colored fruit with reduced marketable yield (Bové, 2006). All commercially available citrus cultivars in the United States are considered susceptible to HLB (Albrecht et al., 2012). This is particularly devastating for Florida's fresh citrus growers, as fruit must maintain cosmetic appearances from harvest through the final purchase.
The HLB epidemic has negatively affected the U.S. market where availability of Florida-based fresh grapefruit can no longer meet consumer demands [U.S. Department of Agriculture (USDA), 2014].

Strategies to mitigate the spread and damage caused by HLB rely heavily upon controlling the insect vector using insecticides (Hall et al., 2013; Stansly et al., 2014). Bassanezi et al. (2013) reported that HLB mitigation in Brazil is built upon maintaining HLB-free nursery trees, removing infected, symptomatic trees in the field, and minimizing ACP activity. In Brazil, area-wide insecticide treatment programs combined with removing infected trees in large regions/areas were shown to be more effective in controlling HLB than programs focused only on small-scale farms (Bassanezi et al., 2013).

Area-wide insecticide applications and tree removal might not be an appropriate strategy for some fresh fruit citrus growers in Florida. High-valued fresh fruit exports must meet stringent chemical residue testing, and area-wide insecticide treatment programs may conflict with the number of applications permitted by the insecticide label and preharvest interval mandates. In addition, area-wide applications of synthetic insecticides will likely preclude further development of organically grown fresh citrus. Insecticide-resistant populations of the ACP have already been detected in citrus-producing regions of Florida (Tiwari et al., 2011). In response to the need of the industry to produce high-quality, HLB-free grapefruit, our research team has embarked upon investigating the feasibility of using totally enclosed antipsyllid screen cloth structures to cultivate fresh citrus fruit.

Covered, protected production fields are needed to ensure the future of fresh citrus production in Florida

\begin{tabular}{llll}
\hline $\begin{array}{l}\text { Units } \\
\begin{array}{l}\text { To convert U.S. to SI, } \\
\text { multiply by }\end{array}\end{array}$ & U.S. unit & SI unit & $\begin{array}{l}\text { To convert SI to U.S., } \\
\text { multiply by }\end{array}$ \\
\hline 0.4047 & acre $(\mathrm{s})$ & $\mathrm{ha}$ & 2.4711 \\
0.3048 & $\mathrm{ft}$ & $\mathrm{m}$ & 3.2808 \\
3.7854 & gal & $\mathrm{L}$ & 0.2642 \\
2.54 & inch $(\mathrm{es})$ & $\mathrm{cm}$ & 0.3937 \\
25.4 & inch $(\mathrm{es})$ & $\mathrm{mm}$ & 0.0394 \\
6.4516 & inch & $\mathrm{cm}$ & 0.1550 \\
0.4536 & $\mathrm{lb}$ & $\mathrm{kg}$ & 2.2046 \\
1.6093 & $\mathrm{mph}$ & $\mathrm{km} \cdot \mathrm{h}^{-1}$ & 0.6214 \\
10.7639 & $\mathrm{~W} / \mathrm{ft}^{2}$ & $\mathrm{~W} \cdot \mathrm{m}^{-2}$ & 0.0929 \\
$\left({ }^{\circ} \mathrm{F}-32\right) \div 1.8$ & ${ }^{\circ} \mathrm{F}$ & ${ }^{\circ} \mathrm{C}$ & $\left({ }^{\circ} \mathrm{C} \times 1.8\right)+32$
\end{tabular}

Horllechnology · October 2017 27(5) 
by preventing the incursion of the ACP into growing areas. This protected cultivation system works by physically excluding contact between the ACP and trees. One of the main advantages of this system is that there is reduced reliance upon frequent insecticide sprays to control psyllids. However, environmental conditions inside such structures must be favorable for growing young trees, and this is a concern for the use of screen houses in Florida.

The purpose of this investigation was to evaluate the effect of screen houses on excluding infective ACP from inoculating citrus trees with HLB and to quantify changes in environmental conditions caused by the screen cloth.

\section{Materials and methods}

Site location. The project started in Nov. 2013 at the University of Florida/Institute of Food and Agricultural Sciences (UF/IFAS) Indian River Research and Education Center in Fort Pierce, FL (lat. $27^{\circ} 26^{\prime} \mathrm{N}$, long. $80^{\circ} 26^{\prime} \mathrm{W}$, elevation $19 \mathrm{ft}$ ). Soil at the site is classified in the Pineda series: loamy, siliceous, and active hyperthermic Arenic Glossaqualfs.

ANTIPSYLLID SCREEN HOUSES. A total of four passively ventilated $1 / 4$ acre $(100 \mathrm{ft}$ wide $\times 120 \mathrm{ft}$ long $\times 14 \mathrm{ft}$ tall) completely enclosed screen houses were built to investigate the possibility of using protective structures to exclude ACP and cultivate fresh grapefruit (Fig. 1A). The screen houses were covered on all sides and top by a 50-mesh monofilament high-density polyethylene antipsyllid screen (Signature Supply, Lakeland, FL) - about one-tenth the length of the average adult ACP (Rogers and Stansly, 2007). The main support for each enclosed, covered structure consisted of pressure-treated, wooden utility poles (Outdoor Living Products, Orlando, FL). Each main support utility pole was fixed to the ground with one guy-wire (1/4-inch-diameter, braided, galvanized steel wire) and attached to two 5 - $\mathrm{ft}$-long earth anchors (both Pierson Supply, Pierson, FL). Support utility poles located in the corner position of each screen house were fixed to the ground with two guywires and four earth anchors.

The antipsyllid screen was attached to the sides of the structure
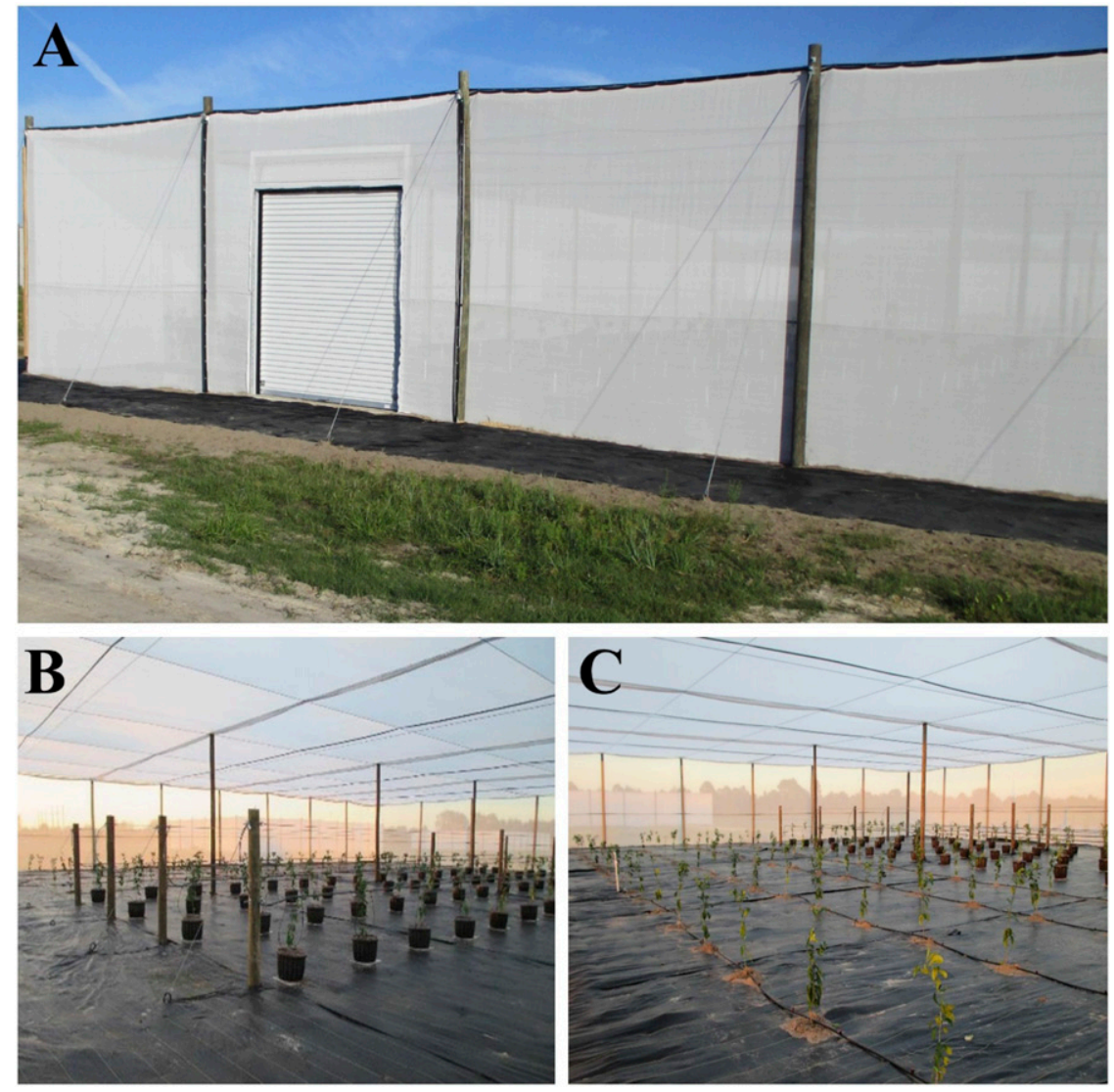

Fig. 1. Protected fresh grapefruit cultivation system for asian citrus psyllid exclusion. (A) Passively ventilated structure with $1 / 4$-acre $(100 \mathrm{ft}$ wide $\times 120 \mathrm{ft}$ long $\times 14 \mathrm{ft}$ tall). The service door is garage-style roll-up and measures $8 \mathrm{ft}$ wide $\times$ $10 \mathrm{ft}$ tall. (B) Potted grapefruit trees on trellises. (C) In-ground grapefruit trees. Both plantings at a density of 792 trees/acre [1951.1 trees/ha (spacing of $5.5 \mathrm{ft}$ in-row and $10 \mathrm{ft}$ between-row) $] ; 1$ acre $=0.4047 \mathrm{ha}, 1 \mathrm{ft}=0.3048 \mathrm{~m}$.

by stapling the cloth to the interior side of the perimeter main support utility poles. The side screen cloth was attached to the top screen cloth with "S"-shaped galvanized steel hooks, and the side screen panels and top screen panels were pleated together, with the resulting seam directed toward the interior of the house. The construction of each screen house included one aluminum rollup garage-style service door $(8 \mathrm{ft}$ wide $\times 10 \mathrm{ft}$ tall). A 12 -ft-wide $\times$ 12 -ft-long $\times 12$-ft-tall antechamber was built to limit insect inclusion when the entrance door is opened.

All four antipsyllid screen houses and open-air plots were surrounded by at least 50 - $\mathrm{ft}$ buffer area to prevent any influence on environmental conditions to the next-nearest screen house and open-air plots.

TreatMenTS AND EXPERIMENTAL DESIGN. We tested two coverings [enclosed screen house and open-air (control)] and two planting systems (in-ground and container-grown), with four replications arranged in a split plot experimental design. Covering was considered as the main plot and planting system as the split-plot. We also tested two rootstocks \{sour orange (Citrus xaurantium) and US-897 ['Cleopatra' mandarin (Citrus reticulata) $\times$ 'Flying Dragon' trifoliate orange (Poncirus trifoliata)]\}. Data were pooled for analysis purposes because of the lack of differences in the first year of cultivation.

Trees AND PLANTING METHODS. 'Ray Ruby' grapefruit trees on sour orange and US-897 rootstocks were purchased from licensed, certified disease-free commercial nurseries [Sawmill Citrus Nursery (Fort Meade, FL) and Brite Leaf (Lake Panasoffkee, FL), respectively]. Trees were planted at a density of 792 trees/acre [1957.1 trees/ha, spacing of $5.5 \mathrm{ft}$ in-row and $10 \mathrm{ft}$ between-row (eight trees/row 
and four rows on screen houses, and eight trees/row and three rows on open-air, totaling 896 trees)]. The same tree density was used in all treatments (Fig. IB and C). Potted trees were planted in 10-gal plastic containers (\#10 Accelerator AP-10; Nursery Supplies, Chambersburg, PA). The plastic containers were filled with a medium consisting $(\mathrm{v} / \mathrm{v})$ of $50 \%$ clean, washed silica sand, $15 \%$ Florida peatmoss, $7.5 \%$ coconut fiber, $20 \%$ cypress sawdust, and $7.5 \%$ perlite (Harrell's, Lake Placid, FL). Plastic growing containers were placed upon 16-inch ${ }^{2}$ ceramic tiles to prevent tree roots from growing into the underlying native soil.

IRRIGATION. Each tree was serviced by two 2 -gal/h flow drip emitters (SB-20; Bowsmith, Exeter, CA). Irrigation scheduling was based on weather data obtained on site. We used two weather stations (WatchDog 2900ET; Spectrum Technologies, Aurora, IL) installed inside two of the screen houses and an additional two stations placed in two of the open-air plots. Trees grown inside the screen houses and open-air plots were watered to replenish the corresponding daily $\mathrm{ET}_{\mathrm{O}}$ (mean of two weather stations)] values for their respective growing environment. From Jan. to July 2014, all trees automatically received daily irrigation volumes that were $\approx 33 \%$ of the total $\mathrm{ET}_{\mathrm{o}}$ value because of lower water demand. From July to Dec. 2014, the trees received daily irrigation volumes that were $100 \%$ of the total $\mathrm{ET}_{\mathrm{o}}$. The trees were not irrigated on days where rainfall was equal to or greater than the $\mathrm{ET}_{\mathrm{O}}$.

Fertigation. We used $15 \mathrm{~N}-$ 2.6P-22.4K water-soluble fertilizer (Agrolution pHLow; Everris NA, Dublin, $\mathrm{OH}$ ) with $15 \%$ total nitrogen [N $(2.6 \%$ ammoniacal and $12.4 \%$ nitrate)], 2.6\% phosphorus (P), 22.4\% potassium $(\mathrm{K}), 3.3 \%$ calcium $(\mathrm{Ca})$, $0.02 \%$ boron (B), $0.05 \%$ cooper $(\mathrm{Cu}), 0.1 \%$ iron $(\mathrm{Fe}), 0.05 \%$ manganese $(\mathrm{Mn}), 0.0005 \%$ molybdenum (Mo), and $0.05 \%$ zinc $(\mathrm{Zn})$. Fertilizer was mixed at a concentration of $150 \mathrm{lb}$ fertilizer per $100 \mathrm{gal}$ water in a 500 -gal plastic stock tank plumbed in-line with the servicing irrigation system. A proportional $40 \mathrm{gal} / \mathrm{min}$ chemical injector (D8RE2; Dosatron International, Clearwater, FL) was installed directly up-stream to the irrigation zone valves and connected to the fertigation stock tank. This injector added fertigation solution to each irrigation event and was adjusted seasonally to increase or decrease the proportional volume of fertigation solution being added to the irrigation stream. The proportional injector's settings changed over time based on nutritional needs by season, and the minimum, maximum, and annual mean of the proportioner $(\mathrm{v} / \mathrm{v})$ were $0.2 \%$ (February), $1.9 \%$ (September), and $0.8 \%$, respectively. The screen houses and the open-air plots received the same amount of fertilizer throughout the study.

Huanglongbing diagnosis. Citrus samples were screened for the presence of CLas. Ten fully expanded leaves and leaf petioles with intact stems from symptomatic branches (if present) were collected in eight trees per plot. HLB diagnostic analysis was done by the quantitative real-time polymerase chain reaction (qRTPCR) tests coupled with USDAapproved primers ( $\mathrm{Li}$ et al., 2006) at the HLB Diagnostic Laboratory of the UF/IFAS Southwest Florida Research and Education Center (SWFREC) in Immokalee, FL.

ENVIRONMENTAL DATA. The same weather stations (WatchDog 2900ET, Spectrum Technologies) used for automated irrigation, installed inside two of the screen houses and in two of the open-air plots, collected and recorded environmental data. All weather stations were mounted on wooden posts $7 \mathrm{ft}$ aboveground. The two stations outside the screen houses were placed from 60 to $110 \mathrm{ft}$ away from their accompanying screen houses to avoid any unwanted shading effects of the screen houses on the weather stations mounted outside. The straight-line distance separating the weather stations within the two individual screen houses was $190 \mathrm{ft}$, and the straight-line distance separating the weather stations in the two individual open-air plots was $\approx 515 \mathrm{ft}$. The weather stations were set to record solar radiation, air temperature, wind gust, and rainfall every $30 \mathrm{~min} . \mathrm{ET}_{\mathrm{o}}$ was calculated daily using the Penman-Monteith equation (Allen et al., 1998). Recording of variables began at $14 \mathrm{~h}$ on $22 \mathrm{Feb}$. and ceased at $12 \mathrm{~h}$ on 31 July 2014 .

Statistical analysis. Number of psyllids was analyzed using analysis of variance (Proc GLM) and Tukey's multiple comparison test (least square means) using SAS (version 9.4; SAS Institute, Cary, NC). Probability values $\leq 0.05$ were considered statistically significant.

Solar radiation values were summed over time but only 7 -d interval (weekly) records were used. Cumulative solar radiation values were regressed against elapsed time (in min) using the "lme" package of the $\mathrm{R}$ programming language (version 3.3.3; R Foundation, Vienna, Austria) (Pinheiro and Bates, 2000). A linear mixed-effect regression model was used to evaluate cumulative solar radiation and elapsed time. Screen houses and open-air were evaluated separately and the sample size were each $n=2$. A random effect for "weather station" was added to the model and a first-order autoregressive correlation coefficient was incorporated into the model to account for serial observations taken from the same weather station. In addition, because elapsed time started with minute zero, the linear mixed-effect equation eliminated an intercept term and forced the model through the origin. Slope estimates from the model outputs were evaluated from open-air vs. inside the screen houses by comparing $95 \%$ confidence intervals. A similar analytical approach was used to regress cumulative values of $\mathrm{ET}_{\mathrm{o}}$ against day of the year. An additional difference was that the intercept term was retained in the regression model of $\mathrm{ET}_{\mathrm{o}}$ vs. day of the year. However, random effect and autoregressive correlation coefficient assignment remained the same as the cumulative solar radiation.

Daily maximum and minimum air temperature, wind gust, and $\mathrm{cu}^{-}$ mulative rainfall were averaged and recorded monthly over the two weather stations [outside $(n=2)$ and inside the screen houses $(n=2)]$. Means were analyzed using linear mixed-effect repeated measures analyses through the "lme" package of R. A random effect was implemented for "weather station" and fixed effects included main effects "month" and "covering" and "month" $\times$ "covering" interaction. A compound symmetry correlation structure was incorporated into the model to account for serial observations on the same weather station. Tukey-adjusted multiple comparison $t$ tests were used to separate means 
of interaction effects using the "multcomp" package in $\mathrm{R}(P \leq 0.05)$.

\section{Results}

The antipsyllid screen cloth effectively excluded the ACP from the screen houses, resulting in the absence of psyllids after establishment (Table 1). The psyllid counting varied from May to August in the open-air, with a peak in June. Container-grown trees had more psyllids than in-ground trees $[P<0.01$ (Table 1$)]$. Open-air trees were diagnosed positive for CLas in Oct. and Dec. 2014. Cycle threshold $(\mathrm{Ct})$ values were $>32$ in-ground and container-grown trees (Table 1 ).

Cumulative solar radiation reached 1.52 and 1.53 million $\mathrm{W} \cdot \mathrm{m}^{-2}$ for the two weather stations placed inside the screen houses, and 1.94 and 1.97 million $\mathrm{W} \cdot \mathrm{m}^{-2}$ for the two weather stations placed in the open-air plots $[P<0.01$ (Fig. 2A)]. The slope estimated from the through-the-origin model output was $6.7 \mathrm{~W} \cdot \mathrm{m}^{-2} \cdot \mathrm{min}^{-1}$ for plots inside the screen houses and $8.6 \mathrm{~W} \cdot \mathrm{m}^{-2} \cdot \mathrm{min}^{-1}$ for open-air plots $(P<0.01)$. Therefore, cumulative solar radiation for the open-air plots was greater than inside the screen houses $[P<0.01$ (Fig. 2A)].

Cumulative $\mathrm{ET}_{\mathrm{o}}$ values reached 508 and $510 \mathrm{~mm}$ for the two weather stations located inside the screen houses, and 649 and $680 \mathrm{~mm}$ for the two weather stations placed in the open-air plots $[P<0.01$ (Fig. 2B)]. The slope estimate from the model output was $3.2 \mathrm{~mm} \cdot \mathrm{d}^{-1}$ for plots inside the screen houses and $4.2 \mathrm{~mm} \cdot \mathrm{d}^{-1}$ for open-air plots $(P<$ $0.01)$. The rate of cumulative $\mathrm{ET}_{\mathrm{o}}$ water loss was greater for the openair plots than for inside the screen houses $[P<0.01$ (Fig. 2B)].

Maximum air temperature was greater inside the screen houses compared with the open-air plots ["month" $\times$ "covering"; $P<0.01$ (Fig. 3A)]. The lowest maximum air temperature inside the screen houses $\left(28.6^{\circ} \mathrm{C}\right)$ was observed in March, and the greatest value inside the screen houses $\left(36.4^{\circ} \mathrm{C}\right)$ was observed in July 2014 (Fig. 3A). In the open-air plots, the lowest maximum air temperature monthly average was $26.2^{\circ} \mathrm{C}$, and the greatest value was $33.1^{\circ} \mathrm{C}$-also observed in July 2014.

There were no differences in monthly averaged minimum daily air temperatures between screen house and open-air plots [ "month" $\times$ " $\mathrm{cov}$ ering"; $P=0.83$ (Fig. 3A)]. The lowest values were observed in Mar. 2014 , with values of 14.4 and $13.8^{\circ} \mathrm{C}$ at the screen houses and open-air plots, respectively. The greatest values were observed in July 2014, averaging 23.7 and $23.0^{\circ} \mathrm{C}$ inside the screen houses and open-air plots, respectively.

Monthly averages of maximum wind gusts were greater in the open-air than inside screen houses ["month" $\times$ "covering"; $P<0.01$ (Fig. 3B)]. The peak of maximum wind gusts inside the screen houses was $6.7 \mathrm{~km} \cdot \mathrm{h}^{-1}$ and in the open-air was $26.8 \mathrm{~km} \cdot \mathrm{h}^{-1}$ in May 2014 (Fig. 3B).

There were no differences in cumulative rainfall between screen house and open-air plots [ "month" $x$ "covering"; $P=0.97$ (Fig. 3C)]. The total cumulative amount of rainfall from February to July was $501 \mathrm{~mm}$ for screen house and $495 \mathrm{~mm}$ for the open-air plots.

\section{Discussion}

No ACP (eggs, nymphs, and adults) and no trees tested positive for CLas were found inside protective screen houses after a year of monitoring, where $17 \%$ to $25 \%$ of surveyed trees in the open-air plots tested positive for CLas (Table 1). The antipsyllid screen houses effectively excluded the HLB vector.

Another important aspect of the new concept of enclosed citrus tree production is to determine if the antipsyllid screen cloth coverings influence ambient environmental conditions inside the houses relative to open-air conditions. The screen cloth reduced both the solar radiation accumulation (Fig. 2A) and the daily rate of $\mathrm{ET}_{\mathrm{o}}$ (Fig. $2 \mathrm{~B}$ ) by $23 \%$ when compared with the open-air plots. In addition to potentially eliminating the threat of HLB, these results indicated enclosed screen houses provided a less stressful environment for fresh citrus fruit cultivation compared with open-air conditions (Ferrarezi et al., 2017).

Table 1. Number of asian citrus psyllids (ACPs), cycle threshold (Ct) value, and huanglongbing disease (HLB) status on 'Ray Ruby' grapefruit growing on different coverings (screen house and open-air) and planting methods (in-ground and container-grown). Average of four replications.

\begin{tabular}{|c|c|c|c|c|c|c|c|c|c|c|}
\hline \multirow[b]{2}{*}{ Covering } & \multirow[b]{2}{*}{ Planting } & \multicolumn{9}{|c|}{ ACPs (no.) } \\
\hline & & Apr. & May $^{\mathrm{z}}$ & June & July & Aug. & Sept. & Oct. & Nov. & Dec. \\
\hline \multirow[t]{2}{*}{ Screen house } & In-ground & 0 & $0 \mathrm{c}$ & $0 \mathrm{c}$ & $0 \mathrm{~b}$ & $0 \mathrm{~b}$ & 0 & 0 & 0 & 0 \\
\hline & Containers & 0 & $0 \mathrm{c}$ & $0 \mathrm{c}$ & & & 0 & 0 & 0 & 0 \\
\hline \multirow[t]{2}{*}{ Open-air } & In-ground & 0 & $3.0 \mathrm{~b}$ & $6.1 \mathrm{~b}$ & $1.9 \mathrm{a}$ & $4.6 \mathrm{a}$ & 0 & 0 & 0 & 0 \\
\hline & Containers & 0 & $4.5 \mathrm{a}$ & $9.0 \mathrm{a}$ & & & 0 & 0 & 0 & 0 \\
\hline$P$ value & Covering $(\mathrm{C})$ & & $<0.0001$ & $<0.0001$ & 0.0047 & $<0.0001$ & & & & \\
\hline
\end{tabular}

\begin{tabular}{|c|c|c|c|c|c|c|c|}
\hline \multirow[b]{2}{*}{ Covering } & \multirow[b]{2}{*}{ Planting } & \multicolumn{3}{|c|}{ Ct value ${ }^{y}$} & \multicolumn{3}{|c|}{ HLB diagnosis } \\
\hline & & Mar. & Oct. & Dec. & Mar. & Oct. & Dec. \\
\hline Screen house & In-ground & - & - & - & - & - & - \\
\hline Open-air & In-ground & - & 31.5 & 32.5 & - & + & + \\
\hline & Containers & - & 33.0 & 30.0 & - & + & + \\
\hline
\end{tabular}

${ }^{2}$ Numbers followed by different letters are significantly different by Tukey's multiple comparison test $(P<0.05)$.

'In a real-time PCR assay, a positive reaction is detected by accumulation of a fluorescent signal. The Ct is defined as the number of cycles required for the fluorescent signal to cross the threshold (i.e., exceeds background level); HLB negative (-), HLB positive (+). 

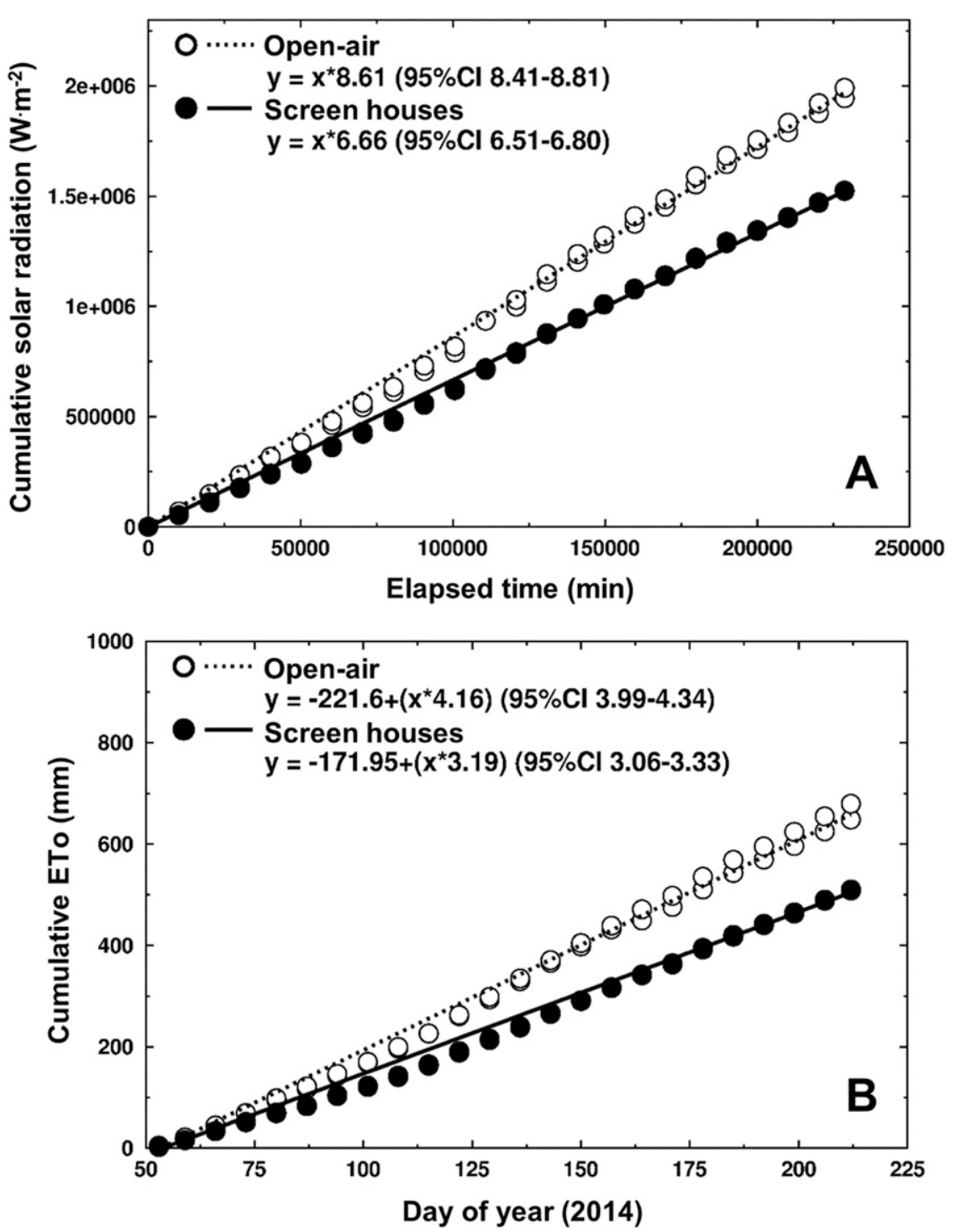

Fig. 2. Cumulative solar radiation (A) and reference evapotranspiration $\left[\operatorname{ET}_{\mathrm{o}}(\mathrm{B})\right]$ inside screen houses and open-air plots. The purpose of screen houses was the exclusion of asian citrus psyllid. Measurements were recorded from $22 \mathrm{Feb}$. to 31 July 2014 every $30 \mathrm{~min}$ and summed for each day, but only points from every $7 \mathrm{~d}$ (weekly) were used in analyses. Each point represents the weekly cumulative measurement of an individual weather station, where $n=2$ for weather stations inside screen houses and open-air plots. Data were analyzed using mixed-effect linear regression using a first-order autoregressive correlation structure to account for serial observations and forced through the origin for solar radiation $[y=x(b)]$. For $\mathrm{ET}_{\mathrm{o}}, y=a+x(b)$. Point estimates of regression slopes are listed along with $95 \%$ confidence intervals (CI). Some points are obscured because of overlap and dashed and solid lines represent model best-fit estimates; $1 \mathrm{~mm}=0.0394 \mathrm{inch}, 1 \mathrm{~W} \cdot \mathrm{m}^{-2}=$ $0.0929 \mathrm{~W} / \mathrm{ft}^{2}$.

Research on the use of completely enclosed structures to cultivate high-valued fresh tree fruit is limited. Lang (2009) reported preliminary results using covered structures to cultivate fresh sweet cherries (Prunus avium) at Michigan State University. That study used a solid polyethylene film as a covering for high tunnels and that author reported the covering reduced transmitted photosynthetically removed the film covering from May to August, and did not observe higher maximum air temperatures inside their structures compared with open-air. The current study demonstrated elevated maximum air temperatures at the screen houses in May, June, and July (Fig. 3A). Lang (2009) reported that wind gusts inside the plastic-film high tunnels were $\approx 8-15 \mathrm{~km} \cdot \mathrm{h}^{-1}$ lower when compared with values recorded outside the structures. Lang's (2009) report is congruous with the current study, although wind gusts were $\approx 20 \mathrm{~km} \cdot \mathrm{h}^{-1}$ greater in the open-air plots for most of the study period, compared with the measurements taken inside the screen houses in this report (Fig. 3B).

To the best of our knowledge, no previous studies exist on citrus that report environmental conditions inside antipsyllid screen houses used to cultivate young grapefruit trees. Prior studies investigating covering citrus trees have focused on using materials purely for their shading properties to explore leaf-water relations. Aluminized shade netting with $50 \%$ transmittance was used by Jifon and Syvertsen (2003) to temporarily cover 4 - to 12 -year-old sweet orange (Citrus sinensis) and grapefruit trees, reporting increases of leaf WUE in shaded foliage compared with sunlit leaves. Similarly, Cohen et al. (2005) reported that grapefruit leaves under $30 \%$ and $60 \%$ shadecloth had leaf water potential values similar to and less negative, respectively, when compared with sunlit control foliage. The antipsyllid screen houses in this study are constructed from a monofilament material that is translucent and not exclusively designed to provide a shading effect; however, there was an approximate $23 \%$ reduction in cumulative solar radiation inside the screen houses relative to open-air plots. This difference may represent a mild reduction in excessive light energy, albeit a potential alleviation of abiotic stress. This may be explained by the fact that maximum net carbon dioxide $\left(\mathrm{CO}_{2}\right)$ assimilation rates are obtained at one-third of full sunlight in Florida $\left[1500-2200 \mu \mathrm{mol} \cdot \mathrm{m}^{-2} \cdot \mathrm{s}^{-1}\right.$ (Jifon and Syvertsen, 2003)].

The antipsyllid screen material did not impede cumulative rainfall during the observational period (Fig. 3C). Published records of historical and current rainfall totals in Florida's 

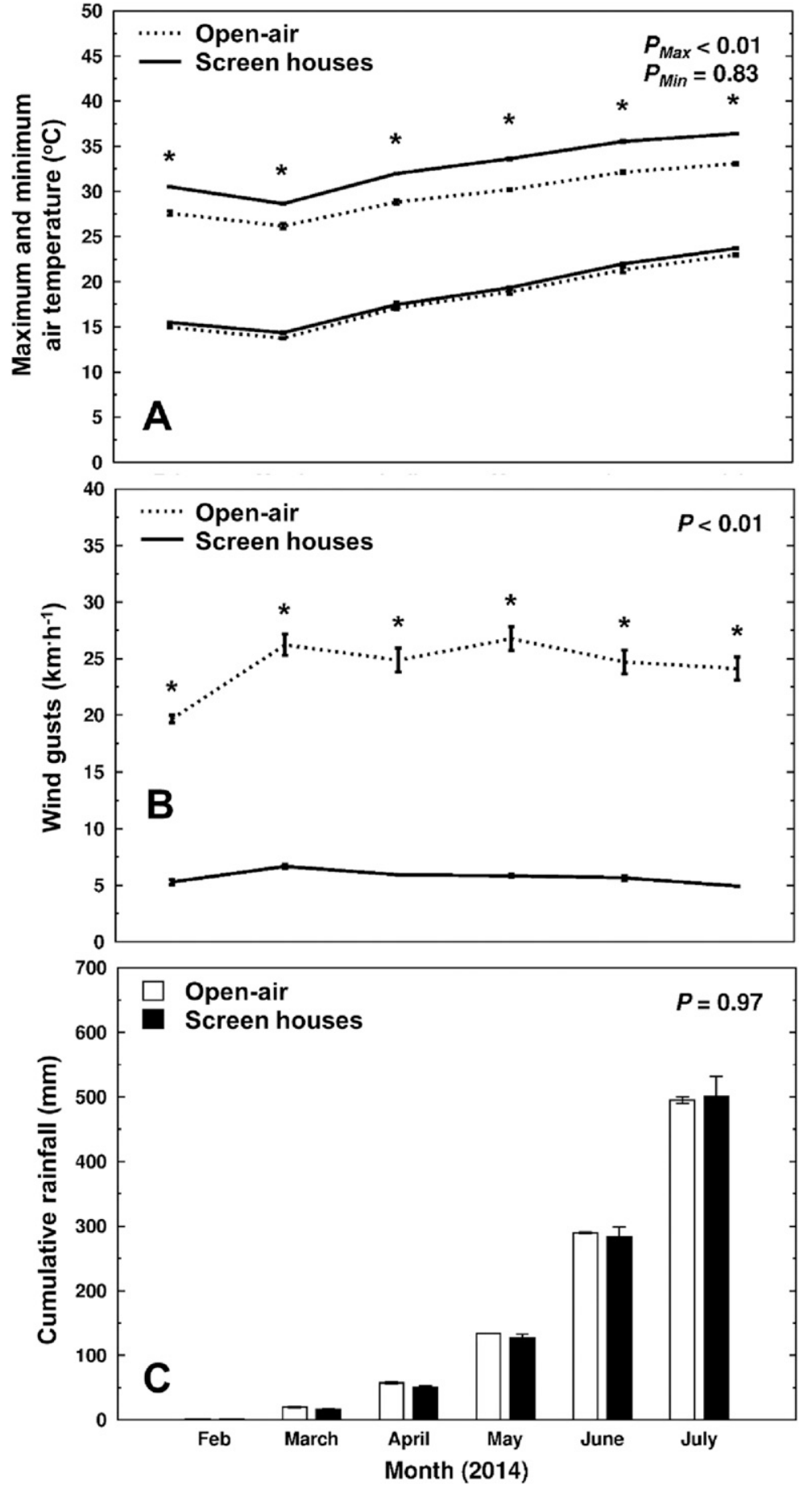

Fig. 3. Maximum and minimum (A) air temperatures, $(B)$ wind gust, and (C) cumulative rainfall inside screen houses and open-air plots. The purpose of screen houses was the exclusion of asian citrus psyllid. Measurements were recorded from $22 \mathrm{Feb}$. to 31 July 2014 every $30 \mathrm{~min}$. Daily gust and rainfall values were averaged for each month. Each peak represents the monthly mean \pm SE of weather stations, where $\boldsymbol{n}=\mathbf{2}$ for weather stations inside screen houses and open-air plots. Data were analyzed using linear, mixed-effect repeated measures implementing a compound symmetry correlation structure to account for serial observations. Probability value listed is associated with the "month" $\times$ "covering" interaction. As appropriate, mean separations were performed using Tukey-adjusted multiple comparison $t$ tests. Asterisks $\left({ }^{*}\right)$ indicate a significant difference $(P \leq 0.05)$ between screen houses and open-air plots means for the respective month. No significant differences were observed in minimum air temperatures and cumulative rainfall between screen houses and open-air plots; $\left({ }^{\circ} \mathrm{C} \times 1.8\right)+32={ }^{\circ} \mathrm{F}, 1 \mathrm{~km} \cdot \mathrm{h}^{-1}=$ $0.6214 \mathrm{mph}, 1 \mathrm{~mm}=0.0394$ inch. citrus-producing regions indicate that the majority of precipitation falls during June, with approximate values nearing $254 \mathrm{~mm}$ in that month (USDA, 2014). In this study, $\approx 210 \mathrm{~mm}$ of rain fell on both the covered screen house and open-air plots (Fig. 3C) during the month of July. It is encouraging that the use of antipsyllid screen cloth to prevent HLB in young citrus plantings will not compromise seasonal rainfall interception rates. Moreover, the weather stations inside the screen houses of this study recorded an approximated $23 \%$ reduction in the rate of daily $\mathrm{ET}_{\mathrm{O}}$ accumulation when compared with the open-air plots (Fig. 2B). Daily $\mathrm{ET}_{\mathrm{o}}$ values for citrus-producing regions in Florida range from 3.2 to $6.5 \mathrm{~mm} \cdot \mathrm{d}^{-1}$ from February to July (Morgan et al., 2006). These values are similar to the daily $\mathrm{ET}_{\mathrm{o}}$ values recorded in this study for the open-air plots (data not shown). The months from October to May receive relatively little to no precipitation in Florida (Parsons and Wheaton, 2000; USDA, 2014). Boman (1994) reported that daily crop evapotranspiration rates of bearing orange trees in southeast Florida from February through April ranged from $\approx 5$ to $75 \mathrm{~mm} \cdot \mathrm{d}^{-1}$. If antipsyllid screen cloth, like the material used in this project, could consistently reduce $\mathrm{ET}_{\mathrm{o}}$ demands on citrus, that might translate to considerably less water stress throughout the year. Growing young grapefruit trees in-ground within antipsyllid screens may offer the benefit of rapidly bringing trees into production that remain HLB free. The ultimate benefit of growing trees in the screen houses will be productivity, which may or may not be well correlated with tree growth. The trees in this study were subjected to variable weather conditions when grown at the open-air plots. In general, trees mildly stressed tend to produce more fruit. Therefore, it is still too early to conclude that the trees in the screen house will be superior to trees in the open-air.

Lang's (2009) results of sweet cherries cultivated under plastic hightunnel structures also noted the reduction of multiple pests and diseases, relative to open-air plots. That report gave qualitative descriptions of declines in arthropod activity and disease incidence of sweet cherry 
cultivars underneath plastic-film high tunnels, although portions of the end panels were opened periodically during the growing season. The screen houses described herein are completely closed on all sides and top. The mesh aperture in our houses was capable of excluding the adult ACP and it is expected that it will lead to prevention of HLB development. In addition, the screen cloth used in this project might be able to reduce the incidence and severity of citrus canker disease, another economically important disease of fresh citrus fruit in Florida. Citrus canker disease is caused by the bacterium Xanthomonas citri and is spread by wind-driven rainfall. Bock et al. (2014) conducted wind tunnel experiments with 'Swingle' citrumelo (Citrus paradise $\times$ Poncirus trifoliata) seedlings and determined that foliar canker disease incidence and severity was greater for wind speeds exceeding 57.6 $\mathrm{km} \cdot \mathrm{h}^{-1}$, compared with wind speeds lower than $18 \mathrm{~km} \cdot \mathrm{h}^{-1}$. In the current report, none of the monthly averages of daily maximum wind gusts exceeded $57.6 \mathrm{~km} \cdot \mathrm{h}^{-1}$; however, wind gusts were nearly static from February through July inside the screen houses and never exceeded an average of $6.7 \mathrm{~km} \cdot \mathrm{h}^{-1}$. Therefore, whereas the citrus canker disease bacterium is capable of passing through the mesh aperture of the antipsyllid screen cloth used in this study, the screen covering acts as an effective windbreak, with the potential to reduce the risk of citrus canker disease spread to inside such covered screen houses.

\section{Conclusion}

The antipsyllid screen excluded the vector of HLB from the screen houses. ACP and HLB-positive trees were found only on trees grown in open-air. The environmental conditions inside the screen houses indicated a reduction in cumulative solar radiation, wind gust, and cumulative $\mathrm{ET}_{\mathrm{o}}$ when compared with open-air plots. These observations have demonstrated that cultivating young citrus trees inside such screen houses may represent a better growing environment compared with conventional open-air plantings. This is important in an era where HLB is widespread throughout all the citrusproducing regions of Florida and replanting of young trees will require added attention to ensure and maintain profitable fresh citrus fruit yields. However, the most significant indicator of substantial merit in using antipsyllid screen houses is the ability to cultivate fresh citrus fruit using covered, protective structures to enhance yield quality.

\section{Literature cited}

Albrecht, U., G. McCollum, and K.D Bowman. 2012. Influence of rootstock variety on Huanglongbing disease development in field-grown sweet orange (Citrus sinensis [L.] Osbeck) trees. Sci. Hort. 138:210-220.

Allen, R.G., L.S. Pereira, D. Raes, and M. Smith. 1998. Crop evapotranspirationguidelines for computing crop water requirements. FAO Irrigation Drainage Paper No. 56.

Bassanezi, R.B., L.H. Montesino, N. Gimenes-Fernandes, P.T. Yamamoto, T.R. Gottwald, L. Amorim, and A.B. Filho. 2013. Efficacy of area-wide inoculum reduction and vector control on temporal progress on huanglongbing in young sweet orange plantings. Plant Dis. 97:789-796.

Bock, C.H., J.H. Graham, T.R. Gottwald, A.Z. Cook, and P.E. Parker. 2014. Effect of the duration of inoculum exposure on development of citrus canker symptoms on seedlings of Swingle citrumelo. Eur. J. Plant Pathol. 138:237-245.

Boman, B.J. 1994. Evapotranspiration by young Florida flatwoods citrus trees. J. Irrig. Drain. Eng. 120:80-88.

Bové, J.M. 2006. Huanglongbing: A destructive, newly-emerging, century-old disease of citrus. J. Plant Pathol. 88:7-37.

Cohen, S., E. Raveh, Y. Li, A. Grava, and E.E. Goldschmidt. 2005. Physiological responses of leaves, tree growth and fruit yield of grapefruit trees under reflective shade screens. Sci. Hort. 107:25-35.

Ferrarezi, R.S., A.L. Wright, B.R. Gruber, B.J. Boman, A.W. Schumann, F.G. Gmitter, and J.W. Grosser. 2017. Protected fresh grapefruit cultivation systems: Antipsyllid screen effects on plant growth and leaf transpiration, vapor pressure deficit, and nutrition. HortTechnology 27:666-674.
Hall, D.G., T.R. Gottwald, E. Stover, and G.A.C. Beattie. 2013. Evaluation of management programs for protecting young citrus plantings from huanglongbing. HortScience 48:330-337.

Jifon, J.L. and J.P. Syvertsen. 2003. Moderate shade can increase net gas exchange and reduce photoinhibition in citrus leaves. Tree Physiol. 23:119-127.

Lang, G.A. 2009. High tunnel tree fruit production: The final frontier? HortTechnology 19:50-55.

Li, W., J.S. Hartung, and L. Levy. 2006. Quantitative real-time PCR for detection and identification of Candidatus Liberibacter species associated with citrus huanglongbing. J. Microbiol. Methods 66:104-115

Morgan, K.T., T.A. Obreza, J.M.S. Scholberg, L.R. Parsons, and T.A. Wheaton. 2006. Citrus water uptake dynamics on a sandy Florida entisol. Soil Sci. Soc. Amer. J. 70:90-97.

Parsons, L.R. and T.A. Wheaton. 2000. Irrigation management and citrus tree responses in a humid climate. HortScience 35:1043-1045.

Pinheiro, J.C. and D.M. Bates. 2000. Mixed-effects models in $S$ and S-Plus. Springer, New York, NY.

Rogers, M.E. and P.A. Stansly. 2007. Biology and management of the asian citrus psyllid, Diaphorina citri Kuwayama, in Florida citrus. Univ. Florida, Inst. Food Agr. Sci., Florida Coop. Ext. Serv. Bul. ENY739.

Santos, B.M. and T.P. Salame-Donoso. 2012. Performance of southern highbush blueberry cultivars under high tunnels in Florida. HortTechnology 22:700-704.

Stansly, P.A., H.A. Arevalo, J.A. Qureshi, M.M. Jones, K. Hendricks, P.D. Roberts, and F.M. Roka. 2014. Vector control and foliar nutrition to maintain economic sustainability of bearing citrus in Florida groves affected by huanglongbing. Pest Mgt. Sci. 70:415-426.

Tiwari, S., R.S. Mann, M.E. Rogers, and L.L. Stelinski. 2011. Insecticide resistance in field populations of Asian citrus psyllid in Florida. Pest Mgt. Sci. 67:1258-1268.

U.S. Department of Agriculture. 2014. Florida citrus statistics 2012-2013. 11 Aug. 2014. <http://www.nass.usda. gov/Statistics_by_State/Florida/ Publications/Citrus/fcs/2012-13/ fcs1213.pdf>. 